\section{Australia prepares to ratify Kyoto Protocol}

Kevin Rudd, Australia's new prime minister, has wasted little time in getting to work on an election pledge to ratify the Kyoto Protocol on greenhouse-gas emissions. Rudd led the Labor party to victory in Saturday's election. The next day, he reiterated his promise to ratify the protocol by Christmas. Ousted leader John Howard refused to ratify Kyoto during his 11-year tenure.

Rudd also confirmed that he plans to head Australia's delegation to the United Nations Climate Change Conference in Bali next week. John Connor, chief executive of the Climate Institute of Australia in Sydney, says the country's changed stance is already

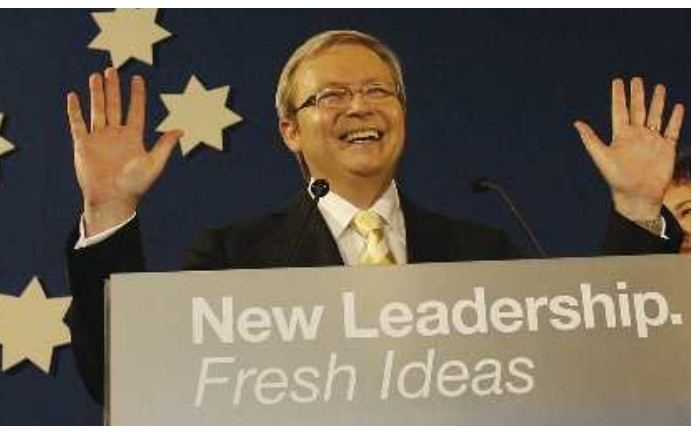

Kevin Rudd, Australia's new prime minister. causing ripples. "It will be a huge boost to the Bali negotiations to have one of the blockers change into a real supporter," he says.

Australia is currently on track to meet its generous Kyoto target of an $8 \%$ increase over 1990 emissions by 2012 .

\section{Italy reappoints institute head despite controversy}

The Italian government has confirmed the reappointment of Enrico Garaci as head of the ISS, Italy's national health-research institute in Rome, despite public criticism of his distribution of research money without peer review (see Nature 450, 320; 2007).

The government accepted his nomination by health minister Livia Turco on 16 November. But a few days later Turco gave Garaci an effective slap on the wrist by halting procedures he had begun for distributing her ministry's $€ 3$-million (US\$4.5-million) fund for stem-cell research. Since the summer, Garaci had failed to issue a call for research proposals, and had earmarked beneficiaries without external review.

Turco has now said the money available will be increased to $€ 8$ million, "for which there will be an open call and evaluation by external referees".

\section{Argentina sets up a ministry of science}

Argentina's newly elected president Cristina Fernandez de Kirchner moved quickly to advance science in her administration, which begins on 10 December.

Lino Barañao was named as the first minister of the newly formed Ministry of Science, Technology and Productive Innovation. Widely respected for his research on animal reproduction and his management of scientific projects, Barañao was president of the National Agency for the Promotion of Science and Technology.

"This is a very good indication for the future direction of science in Argentina," says Juan Pablo Paz, a physicist at the University of Buenos Aires. "It is better than appointing a politician in the old-fashioned style."

\section{Indonesia edges closer to sharing bird-flu samples}

A deal is being negotiated that could see Indonesia end its policy of withholding samples from human cases of avian flu.

Until now, Indonesia has refused to share its samples with the World Health Organization (WHO), saying it is unfair that 